\title{
Home intervention model to promote physical activity in female older adults
}

\author{
Modelo de intervenção domiciliar para promoção de exercício físico em idosas
}

\section{AUTHOR'S \\ Maria da Conceição Lopes Ribeiro ${ }^{1}$ (iD) \\ Lélia Lessa Teixeira Pinto ${ }^{2}$ (D) \\ Andrêza Soares dos Santos ${ }^{3}$ (D) \\ Joilson Menegucci ${ }^{4}$ (D) \\ Jair Sindra Virtuoso Junior ${ }^{5}$ (D) \\ Sheilla Tribess 5 iD \\ 1 Federal University of Piaui, Department of Physical Education, Teresina, Piaui, Brazil. \\ 2 Bahia Southeast State University, Graduate Program in Nursing and Health, Jequie, Bahia, Brazil. \\ 3 University of Minas Gerais, Department of Physical Education, Sao Joao Del-Rei, Minas Gerais, Brazil. \\ 4 Federal University of Triangulo Mineiro, Graduate Program in Health Care, Uberaba, Minas Gerais, Brazil. \\ 5 Federal University of the Triangulo Mineiro, Graduate Program in Physical Education, Uberaba, Minas Gerais, Brazil.}

\section{CORRESPONDING}

Maria da Conceição Lopes Ribeiro lopeseis@gmail.com

Rua Júlio Pinto da Rocha, n 224, bairro Santo Antônio, Timon, Maranhão, Brasil. CEP: 65630-490.

DOI

$10.12820 /$ rbafs. $23 \mathrm{e} 0043$

\section{cc) (1) $(9)$

BY NG ND

Copyright: This is an open-access article distributed under the terms of the Creative Commons Attribution License ${ }^{\circledR}$, which permits unrestricted use, distribution, and reproduction in any medium, provided that the original author and source are credited.

\begin{abstract}
The aim of the study was to describe the logical model of a home intervention using a motivational strategy to improve physical fitness components in female older adults. A quasi-experimental study was conducted with 91 elderly women between 61 and 80 years old, divided into intervention (IG) and control (CG) groups. The participants also answered a questionnaire with sociodemographic information, stage of behaviour change, physical activity and physical performance tests, before and after 12 weeks of intervention. The intervention was performed using a guide with home-based physical exercise associated with motivational strategies (telephone calls and home visits). The intervention with reduced interaction was planned to have a low financial cost, both in relation to the physical space and the materials necessary to practice the home-based physical activities, making feasible the applicability in different places. The logical model provides insight into the intervention and its phases of planning, implementation, and evaluation.
\end{abstract}

Keywords: Intervention studies; Health of the elderly; Physical activity.

RESUMO

O objetivo do estudo foi descrever o modelo lógico de uma intervenção domiciliar utilizando estratégia motivacional para melhora dos componentes de aptidão física em mulheres. Foi realizado um estudo quase-experimental, com 91 idosas, entre 61 e 80 anos, divididas em grupo intervenção (GI) e controle (GC). As idosas responderam um questionário com informaçôes sociodemográficas, estágio de mudança de comportamento, atividade física e realizaram testes de desempenho físico, antes e após 12 semanas de intervenção. A intervenção foi realizada com o uso do guia domiciliar de exercícios físicos associado a estratégias motivacionais (ligaçôes telefônicas e visitas domiciliares). A intervenção com interação reduzida foi planejada para ter um baixo custo financeiro, tanto em relação ao espaço físico quanto aos materiais necessários à prática do exercício físico domiciliar, viabilizando a aplicabilidade em diferentes locais. O modelo lógico fornece uma visão da intervenção e das fases de planejamento, implementação e avaliação.

Palavras-chave: Estudos de intervenção; Saúde do idoso; Atividade física.

\section{Introduction}

Ageing is characterized as a continuous, progressive, natural, and irreversible process that results in damage and alteration of morphological, functional, biochemical, and psychological systems and consequently reduces the functional reserves of organs and systems ${ }^{1}$. These modifications, associated to inadequate health behaviors, are factors that could increase the risk of incapacitating processes for the elderly ${ }^{2}$.

Studies in Brazilian populations showed that women had a higher prevalence of functional incapacity when compared to $\mathrm{men}^{2}$, and there is an increase in the level of functional incapacity or limitation with age ${ }^{3}$. The anticipation to incapacitating processes is an important 
public health concern. In parallel with the increase o folder adults in the country, this population tends to decrease quality when performing day to day life tasks, being more exposed to incapacitating processes ${ }^{4}$.

Therefore, the prevention on functional limitations and consequently the delay in incapacitating processes make the development of interventions directed at the improvement of fitness components effective strategies for the older populations ${ }^{5,6}$. These interventions can be conducted at different levels (individual, specific groups, and populations), contexts (clinical, schools, work place, media, and home), and approaches (individual counseling, education, regulations, environmental changes) $)^{7,8}$ and have strategies based on Psychology's theoretical models for behavior change related to physical activity ${ }^{7-10}$.

Among the intervention proposals, the use of guides for home-based physical exercise has been prominent in older populations with the use of booklets and posters with illustrations of simple physical exercises to be used by participants at home ${ }^{10-12}$. Nonetheless, information on these interventions in Brazil are scarce in primary care . $^{8}$

There is the need to broaden interventions to regions with diverse social and cultural characteristics, based on behavioral theoretical models and its respective strategies to improve the health of older adults in Brazil. In this context, the guide for home-based physical exercise is a simple home-based intervention strategy that can be easily applied among older adults.

Therefore, this study aims to describe the logical model of a home-based intervention using a motivational strategy for improvement of physical fitness in female older adults.

\section{Methods}

This is a quasi-experimental study conducted with women ages 60+ years old, residing in the city of Uberaba, Minas Gerais, Brazil. Participants were registered in five Health Units surrounding the headquarters for the Graduate Program in Physical Education at the University of Triangulo Mineiro (PPGEF-UFTM). The city of Uberaba has $12 \%$ of its population over 60 years old, three sanitary districts with 52 Health Units formed by Primary Care Unit, Family Health Unit, and Matrix Health Unit.

Criteria were adopted for inclusion such as being in of the behavior change stages of pre-contemplation, contemplation, or preparation for physical activity ${ }^{14}$, and not being physically active for leisure $(<10$ contin- uous minutes for leisure with the International Physical Activity Questionnaire ${ }^{15}$ ).

Exclusion criteria were considered such as visual and auditory impairment self-reported by participants that could interfere with participation, institutionalizations, orthopedic limitations (use of canes, walkers, or wheelchairs), not having a telephone for contact, being unable to read, understand and/or register the information on the flyer.

A total of 104 female older adults were recruited by convenience (Figure 1), which filled the pre-established criteria, corresponding to an $85 \%$ power, size of sample effect of 0.28 and alpha error of $p<0.050$ (GPower 3.1.7). Participants were allocated into intervention (IG) and control (GC) groups. Due to logistics and monitoring of the intervention, participants residing nearer to the PPGEF-UFTM were selected for the IG and the further on the CG.

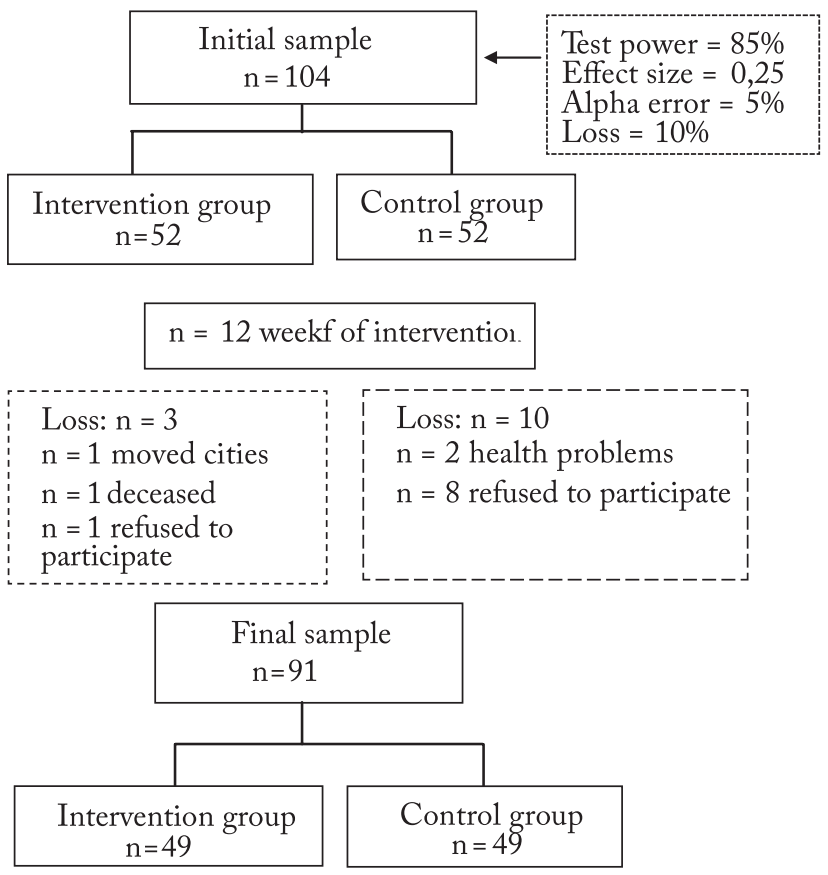

Figure 1- Chart of participant selection for the intervention study with the Guide for home-based physical exercise. Uberaba, Minas Gerais, Brazil, 2014 ( $\mathrm{n}=104)$.

During the 12 weeks of the intervention, there were home visits and phone calls to reiterate the importance in the use of the guide for home-based physical exercise and stimulate adherence to the intervention program. All contact with participants was based on their individual behavior stage.

The description of the activities, as well as frequency, duration, type, and intensity of proposed physical exercises for interventions are described in Chart 1. 
Chart 1 - Description of proposed activities in the guide for homebased physical exercises. Uberaba, Minas Gerais, Brazil, 2014.

\begin{tabular}{|lccc|}
\hline \multicolumn{1}{|c}{ Activity } & Repetition & Duration & Frequency \\
\hline Increased strength and balance & & & \\
Twisting wet cloth & 3 sets & 30 seconds & 2-4 times/week \\
Squeeze rubber balls with & 3 sets & 30 seconds & $2-4$ times/week \\
hands & & & \\
Sit and stand from chair & 3 sets & 30 seconds & 2-4 times/week \\
Cardiovascular Resistance & & & \\
Stationary walking & 3 set & 1 minute & $4-7$ times/week \\
Flexibility & & & \\
Stretching with rope & 3 sets & $20-30$ seconds & Daily \\
Memory & & & Daily \\
Memory games & $1-2$ times & & \\
\hline
\end{tabular}

This study established the initial goal to perform physical activities three times per week, which could increase to up to five times per week according to the development of the intervention. The establishment of long-term goals results in personal change, but there is also higher influence to control current behavior while short term goals can help reach success ${ }^{8,14,15}$.

The evaluation plan included the process as well as the results. In order to evaluate the results, interviews were conducted, physical fitness tests, and blood draws at baseline and at the end of the 12 weeks ( 3 months) of intervention with the use of the guide for homebase physical exercise. To assess the process, home visits were conducted, phone calls during the intervention and monthly logs at the end of each month, which indicated the performance of the exercises described in the guide. All evaluations were conducted at the participants' homes.

The activities developed for effectiveness of the intervention (staff training, materials, initial and final evaluations) as well as the strategies adopted for adherence and adhesion of participants through the 12 weeks (three months) of intervention are described in Chart 2.

The approach for intervention was based in theories at the individual level (Transtheoretical Model of Behavior Change $)^{14}$. The Transtheoretical Model of Behavior Change was developed as a global compartmental model, unifying cognitive, behavioral, and temporal aspects. It integrates six stages for behavior change: precontemplation, contemplation, preparation, action, maintenance, and termination, in which people have different motivations for change and may recycle many

Chart 2 - Description of intervention components and activities as part of adherence strategies for the intervention with the guide for homebased physical exercises. Uberaba, Minas Gerais, Brazil, 2014.

\begin{tabular}{|c|c|}
\hline Activities & Description \\
\hline & Training and creating materials \\
\hline Training of researchers & Training of researchers for application of evaluation instruments and intervention. \\
\hline Guide & Planning and creation of the physical exercise kit: folder of the guide for home-based physical exercises. \\
\hline \multicolumn{2}{|l|}{ Initial assessments } \\
\hline \multirow[t]{2}{*}{ Survey } & Interviews conducted by researchers \\
\hline & Strategies for adherence to intervention. \\
\hline \multicolumn{2}{|l|}{ First month } \\
\hline Help relationships & $\begin{array}{l}\text { Interaction of older adults and people in their familiar environment in the process of intervention, aiming at } \\
\text { behavior change. }\end{array}$ \\
\hline Awareness of the problem & $\begin{array}{l}\text { Explanation about the functional limitations in the process of ageing and the importance for regular physical } \\
\text { activity in the maintenance of functional capacity. }\end{array}$ \\
\hline Delivery of physical exercise kits & Containing the guide for physical exercises, two rubber balls, rope, memory game, and monthly log. \\
\hline \multirow[t]{2}{*}{ Home visit } & $\begin{array}{l}\text { Eight visits were conducted for instructing on the use of the physical exercise kit, filling out the monthly log, } \\
\text { encouraging and motivating physical activity. }\end{array}$ \\
\hline & Second month \\
\hline Home visit & $\begin{array}{l}\text { Two visits to minimize the difficulty of physical exercise and individual verbal reinforcement according to } \\
\text { personal limitations. }\end{array}$ \\
\hline \multirow[t]{2}{*}{ Phone call } & Two phone calls to stimulate motivation for continuing use the guide. \\
\hline & Third month \\
\hline Home visit & One visit to verify engagement using the guide and encourage continuing the physical exercises. \\
\hline \multirow[t]{2}{*}{ Phone call } & $\begin{array}{l}\text { Three phone calls to monitor engagement in the program and stimulate physical exercises described in the } \\
\text { guide. }\end{array}$ \\
\hline & Final assessments \\
\hline Survey & Interviews conducted by researchers. \\
\hline
\end{tabular}


times among the stages until change occurs, therefore being a circular model ${ }^{15}$.

Data collection was conducted with a questionnaire in the form of an individual interview and it included sociodemographic, evaluation of the stage of behavior change, levels of physical activity, and physical fitness tests. The data collection team was composed by Physical Education professionals previously trained in order to standardize all questions and explanations, materials (flyer), approach (interaction with participants and people in their home environment), and awareness on the importance of maintaining and improving physical fitness components, as well as benefits of physical activity and monitoring of the intervention (guidance on the use of the guide, home visits, and telephone calls). Training was conducted at PPGEF-UFTM and was coordinated by a researcher with experience in previous similar studies.

Sociodemographic questions were used to characterize the sample: age, marital status, education, work status, family arrangement, and household income (amount of minimum wages). An adapted instrument from Dumith et al. ${ }^{14}$ was used to standardize the measurement of the stages referring to regular physical activity, classifying participants into: precontemplation, contemplation, preparation, action, and maintenance.

The level of physical activity was measure by the International Physical Activity Questionnaire ${ }^{13}$ adapted for older adults. Questions include physical activity in five domains: work, transportation, domestic activities, leisure, and time spent sitting. Functional physical fitness was assessed through Fullerton's physical fitness performance tests ${ }^{16}$, composed by upper and lower limbs' flexibility; muscle strength and resistance for upper and lower limbs, cardiovascular resistance and dynamic agility and balance.

Data entry was done in Epidata 3.1 software and analysis used the Statistical Package for the Social Sciences (SPSS) software, version 21.0. Descriptive analysis (frequencies) was performed to characterize participants' sociodemographic at baseline. Chisquared test was used to verify the distribution of sociodemographic variables between control and intervention groups at baseline and after intervention. Level of significance was kept $\mathrm{p} \leq 0.050$.

This study was approved by the Ethics and Research in Human Beings' Committee at the University of Triangulo Mineiro no 712467/2014. The participants signed a consent form.

\section{Results}

The intervention included 104 female older adults who began the intervention between the ages of 60 and 80 years old, with a mean age of 70.28 years $(\mathrm{SD}=4.53)$. Sociodemographic characteristics of participants in the control and intervention groups at baseline had no significant differences $(\mathrm{p}>0.050)$.

Overall, most participants were 70 to 80 years old (57.7\%), widowed (43.3\%) or married/living with a partner (35.6\%), residing in multigenerational households (49\%), specifically bigenerational (22.1\%, grandmothers and children), with a low educational level, between one and four years of education (75\%), 45.2\% were retired or received pension, and had low household income (56.7\%).

Figure 2 shows the logical model of this study, which was developed based on the inverse logical approach as suggested by the United States Department of health and Human Services ${ }^{17}$. The goal of the logical model was to provide reference to be used during all phases of planning, implementation, and evaluation of the program.

The model includes resources, activities, and its respective products in addition to initial, intermediate, and long-term results. There is also a view of the final goal (or effect) of the intervention as a reference to all the stages of the process.

The model begins by referencing functional incapacity as a problem that justifies the intervention to precede incapacitating processes, essential for maintenance and autonomy of the older adult. Simple physical exercises that can be easily executed in the home environment may contribute to independent and active older adults, not only at home but in the community.

The execution of the intervention emphasized the following actions: a) adequate use of the home guide; b) improvement in the levels of physical fitness due to the exercises; and c) the development of motivational strategies such as personal, phone contact and motivational messages.

On the effectiveness of the intervention, there was interaction between the participants and people in their home environments, leading to behavior change while in the intervention. There was a focus on increasing awareness about the importance of higher levels of physical activity, risks to health caused by the lack of physical activity, and also the possibility of being active with the guide for home-based exercise and improving health. The reflection was made based on the likely 


\section{PROBLEM}

The increase in functional disability in the elderly population results in the increase of dependency, limiting the elderly when performing socially defined roles and accomplishing daily tasks in a sociocultural environment.
ASSOCIATED FACTORS ${ }^{1}$

Resistence for behavior change (-)

Family commitment $(+)$ and $(-)$

Telephone follow-up $(+)$

Home visits (+)

\section{RESOURCES}

Financial Resources:
UFTM and CAPES.
Human Resources:
Female older adults, researchers, and
families.
Material Resources:
Surveys;
Intervention kits (folder, rubber balls, rope,
and image games);
Materials for blood draw and analysis
(chemicals, alcohol, cotton balls, EDTA
tubes, needles, and bandages).

\section{OBJECTIVES}

To maintain the self-sufficiency of older adults;

To minimize functional limitations and, consequently, functional disability.

\section{ACTIVITIES}

\begin{tabular}{|c|c|}
\hline ACTIVITIES & PRODUCTS \\
\hline \begin{tabular}{|l} 
- Planning and creating the guide for \\
physical exercises; \\
- Training of researchers; \\
- Initial assessment: surveys, physical \\
fitness tests and blood analysis; \\
- Delivery of materials for the intervention; \\
- Phone calls; \\
- Weekly visits; \\
- Final assessment: surveys, physical fitness \\
tests and blood analysis;
\end{tabular} & $\begin{array}{l}\text { - } 104 \text { kits for intervention; } \\
\text { - } 10 \text { trained evaluators; } \\
\text { - } 104 \text { printed surveys; } \\
\text { - } 2 \text { kits for physical fitness testing; } \\
\text { - } 3 \text { kits for biochemical analysis; } \\
\text { - } 11 \text { home visits and } 5 \text { phone calls for } \\
\text { intervention group and } 2 \text { home visits } \\
\text { for control group; } \\
\text { - } 195 \text { evaluations during intervention. }\end{array}$ \\
\hline \multicolumn{2}{|l|}{ MEDIUM AND LONG TERM RESULTS } \\
\hline \multirow[b]{2}{*}{$\begin{array}{l}\text { Adherence to the intervention; } \\
\text { Improvement in physical fitness componentes } \\
\text { (strength, flexibility, cardiovascular resistance); } \\
\text { Greater autonomy for physical activity; } \\
\text { Improvement in biochemical markers (glycemic, } \\
\text { HDL, total cholesterol, triglicerides); } \\
\text { Increase in knowledge on the benefits of physical } \\
\text { activity for health; }\end{array}$} & INITIAL RESULTS \\
\hline & $\begin{array}{l}\text { Adherence of participants to the } \\
\text { intervention; } \\
\text { Correct filling of monthly log; } \\
\text { Improvement in the execution of } \\
\text { movements described in the guide for } \\
\text { physical exercises. }\end{array}$ \\
\hline
\end{tabular}

Figure 2 - Logical model for intervention using the Guide for home-based physical exercises in female older adults. Uberaba, Minas Gerais, Brazil, 2014 ( $\mathrm{n}=104)$.

$(+)$ = positive associated factors. $(-)=$ negative associated factors.

results of the action: increase in regular levels of physical activity due to performance of simple home-based physical exercise in the guide.

The financial investment for an intervention may influence its replication and dissemination. In this study, approximately $\mathrm{R} \$ 6.00$ (six brazilian reais) were used to assemble each kit. The guide kit provided to participants in the IG: a flyer, two rubber balls of $5 \mathrm{~cm}$ width, a rope, and a memory game with pictures of animals, colors, fruits, vehicles; besides the list of exercises, including: cloth twisting and a chair for sitting and standing.

\section{Discussion}

After 12 weeks of intervention, the presente study verified the effectivity of aguide for home-based exercise on behavior change. These findings justify and confirm the importance of interventions with reduced interactions and with low intensity physical activity easily appliable to older adults.

Motivational strategies based on the Transtheoretical Model for Behavior Change were effective in the promotion of physical activity during the program and in other physical activity programs ${ }^{8}$. Therefore, it is highlighted the need for further development of interventions for behavior change in physical activity based on theoretical models once they contribute in the stages of the process, planning, setting aims, implementation, and evaluation of the intervention ${ }^{7}$.

The information from this study provide aid for development of simple and accessible intervention strategies. Besides interventions being based on theoretical models, there is a need to have them planned according to the stage of behavior change ${ }^{14}$, including a variety of mechanisms to support people in the different stages such as those not ready, regularly involved, and those oscillating ${ }^{14}$.

The physical exercises described in the guide were planned considering current recommendations for physical exercise prescription for older adults and took into consideration components of physical fitness that are essential for daily life of older adults such as localized muscular strength and resistance, cardiovascular resistance, flexibility, and balance, besides an activity to stimulate memory. All of the proposed exercises were simple and of easy execution in the home environment 
and did not require supervision since they were developed from activities adapted to simulate daily life o folder adult such as sitting and standing up from a chair, squeeze a rubber ball, twist a piece of cloth, raise the leg to $90^{\circ}$ flex in walking position to the height of the hip.

The intervention with reduced interaction was planned for a low financial cost, relating to physical space as well as materials necessary for home-based physical activity, also allowing for its application in various locations. The use of phone calls and home visits to encourage and follow-up on the development of the activities maximized adherence during the intervention, and these strategies may have influence behavior change. Thus, strategies for intervention with older adults aiming at using the home environment are good alternatives to minimize functional decline with the increase of age.

A few considerations are important for this study. As a strength, this study presented an intervention in the home environment, which could encourage and facilitate the engagement of older adults in physical exercise; the development of the guide and its corresponding materials at a low cost, making this intervention easily replicable; and at last, the fact that a 12 week program, with recommendation of simple low intensity exercises was able to significantly improve some of the components of physical fitness.

As limitations, it is important to highlight the loss of some participants during the study; the lack of control of diet and medications of participants; the period of 12 weeks which could have not been enough; the sample being by convenience and exclusive of women. Nonetheless, women are more likely to get function limitations $^{18}$ and statistical power of the sample remained high even with the loss of participants during the intervention.

This intervention study based on the Transtheoretical Model for Behavior Change promoted improvement in some components of physical fitness such as upper and lower body and cardiovascular of female older adults. The proposal of strategies that favor the adoption of active behaviors must be prioritized in actions for health, since adopting an active lifestyle contributes to minimizing the damage to the health of older adults and even reduce mortality resulting from illness, incapacity, and loss of mobility.

\section{Conflict of interest}

The authors declare no conflict of interest.

\section{Acknowledgment}

The authors thank the students from the Núcleo de Pesquisa em Atividade Física e Saúde (NEAFISA/UFTM) for their collaboration on data collection.

\section{Authors' contributions}

Ribeiro MCL and Tribess S, participated in the conceptual, design, analysis, and interpretation of data, writing and critical review of the manuscript, and approval of the final version for publication. Santos AS, Pinto LLT, JS Virtuoso Junior and Menegucci J, participated in the initial conceptualization of the study, writing, and critical review of the manuscript, data collection, and approval of version for publication.

\section{Funding}

Fundação de Amparo à Pesquisa do Estado de Minas Gerais FAPEMIG (APQ-01023-14). Coordenação de Aperfeiçoamento de Pessoal de Ensino Superior - CAPES (scholarship received during the Master's degree and the length of this research).

\section{References}

1. Cipriani NCS, Meurer ST, Benedetti TRB, Lopes MA. Functional fitness of physically active female older adults. Rev Bras Cineantropom Desempenho Hum. 2010;12(2):106-11.

2. Campos ACV, Almeida MHM, Campos GV, Bogutchi TF. Prevalence of funtional incapacity by gender in Brazilian older adults: a systematic review with metanalysis. Rev Bras Geriatr Gerontol. 2016;19(3):545-59.

3. Moraes SA, Lopes DA, Freitas ICM. Avaliação do efeito independente de doenças crônicas, fatores sociodemográficos e comportamentais sobre a incapacidade funcional em idosos residentes em Ribeirão Preto, SP, 2007 - Projeto EPIDCV. Rev Bras Epidemiol. 2015;18(4):757-70.

4. Den Ouden ME, Schuurmans MJ, Arts IE, Van der Schouw YT. Physical performance characteristics related to disability in older persons: a systematic review. Maturitas. 2011;69(3):208-19.

5. Vagetti GC, Barbosa Filho VC, Moreira NB, Oliveira VD, Mazzardo O, Campos WD. Association between physical activity and quality of life in the elderly: a systematic review, 2000-2012. Rev Bras Psiquiatr. 2014;36(1):76-88.

6. MacMillan F, Fitzsimons C, Black K, Granat MH, Grant MP, Grealy M, et al. West End Walkers 65+: a randomised controlled trial of a primary care-based walking intervention for older adults: study rationale and design. BMC Public Health. 2011;11(1):1-12.

7. Glanz K. Teoria num Relance. Um Guia para Prática da Promoção da Saúde. In: Sardinha L, Matos M, Loureiro I, editors. Promoção da Saúde: Modelos e Práticas de Intervenção nos Âmbitos da Actividade Física, Nutrição e Tabagismo. Lisboa: Faculdade de Motricidade Humana; 1999. p. 10-54.

8. Burke L, Lee AH, Jancey J, Xiang L, Kerr DA, Howat PA, et al. Physical activity and nutrition behavioural outcomes of a home-based intervention program for seniors: a randomized controlled trial. Int J Behav Nutr Phys Act. 2013;10(1):14.

9. Jancey JM, Lee AH, Howat PA, Burke L, Leong CC, Shilton T. The effectiveness of a walking booster program for seniors. Am J Health Promot. 2011;25(6):363-67. 
10. Costa EF, Andrade DR, Garcia LMT, Ribeiro EHC, Santos TI, Florindo AA. Avaliação da efetividade da promoção da atividade física por agentes comunitários de saúde em visitas domiciliares. Cad Saude Publica. 2015;31(10):2185-98.

11. Almeida GM, Silva DMF. Efetividade de uma intervenção de atividade física em adultos atendidos pela estratégia saúde da família: Programa Ação e Saúde Floripa BRASIL. Rev Bras Ativ Fis Saúde. 2012;13(1):44-56.

12. Müller AM, Khoo S. Non-face-to-face physical activity interventions in older adults: a systematic review. Int J Behav Nutr Phys Act. 2014;11(1):35.

13. Mazo GZ, Benedetti TRB. Adaptação do questionário internacional de atividade física para idosos. Rev Bras Cineantropom Desempenho Hum. 2010;12(6):480-4.

14. Dumith SDC, Domingues MR, Gigante DP. Estágios de mudança de comportamento para a prática de atividade física: uma revisão da literatura. Rev Bras Cineantropom Desempenho Hum. 2008;10(3):301-07.
15. Nigg CR, Geller KS, Motl RW, Horwath CC, Wertin KK, Dishman RK. A Research Agenda to Examine the Efficacy and Relevance of the Transtheoretical Model for Physical Activity Behavior. Psychol Sport Exerc. 2011;12(1):7-12.

16. Rikli RE, Jones CJ. Functional fitness normative scores for community residing older adults, ages 60-94. J Aging Phys Act. 1999;(7):162-81.

17. Health USD, Services H. Physical activity and health: a report of the Surgeon General. diane Publishing; 2002.

18. Parahyba M, Veras R, Melzer D. Incapacidade funcional entre as mulheres idosas no Brasil. Rev Saúde Pública. 2005;39(3):383-91.

\section{Quote this article as:}

Ribeiro MCL, Pinto LLT, Santos AS, Menegucci J, Virtuoso Junior JS, Tribess S. Home intervention model to promote physical activity in female older adults. Rev Bras Ativ Fís Saúde. 2018;23:e0043. DOI: 10.12820/rbafs.23e0043 